\title{
Outcrossing Rate and Genetic Variability in Mexican Race Avocado
}

\author{
Enrique I. Sánchez-González and Adriana Gutiérrez-Díez \\ Universidad Autónoma de Nuevo León, Facultad de Agronomía, General Escobedo, Nuevo León, \\ 66054, México \\ Netzahualcóyotl Mayek-Pérez \\ Universidad México-Americana del Norte, Reynosa, Tamaulipas, 88640, México
}

\begin{abstract}
AdDITIONAL INDEX WORDS. ISSR, outcrossing, Persea americana, var. drymifolia, SSR
Abstract. The blooming behavior of the avocado Persea americana Mill. is a sophisticated mechanism that prevents effective self-pollination, enables close pollination, and encourages cross-pollination. However, there is no information on outcrossing rate among Mexican race avocado genotypes (P. americana var. drymifolia Schltdl. \& Cham.). Therefore, the objective of this study was to assess the outcrossing rate and genetic variability in progenies of Mexican race avocado genotypes by simple sequence repeat (SSR) and intersimple sequence repeat (ISSR) markers. SSR marker analysis showed a considerable genetic differentiation among avocado families [total expected heterozygosity $(\mathrm{He})=0.540$ ], whereas the total heterozygosity value observed $(\mathrm{Ho}=0.098)$ showed the presence of genetic structure per family. The total Nei's unbiased average heterozygosity (nHe) value found with ISSR markers was 0.482. The results of the analysis of molecular variance (AMOVA) combining both type of markers showed that genetic variation within avocado families was $58.6 \%$, and among families was $41.6 \%(P<0.0001)$. The outcrossing population rate in $P$. americana var. drymifolia was $0.774 \pm 0.091$ (SD), and the 'Criollo 3' and 'Plátano Temprano' families showed the lowest $(-0.083 \pm 0.031)$ and highest $(0.814 \pm 0.060)$ outcrossing rates, respectively. Variability in outcrossing rate depends on many factors, including edaphoclimatic, agronomic, and genetic, and needs to be considered to define strategies for the conservation and genetic improvement of outstanding native genotypes. SSR and ISSR markers are useful for estimating genetic variability within and among families of avocado, as well as for determining the outcrossing rates among closely related individuals and with a rather small sample size.
\end{abstract}

Avocado is one of the most economically important subtropical/tropical fruit crops in the world (Bost et al., 2013) and is culturally valuable in Mexico. It is member of the Lauraceae family and there are three different ecological races or botanical varieties widely recognized by horticulturists: Mexican $(P$. americana var. drymifolia), Guatemalan ( $P$. americana var. guatemalensis L.O. Williams.), and West Indian (P. americana var. americana Mill.), which are originally from highland Mexico, highland Guatemala, and lowland (coastal) Guatemala to Costa Rica, respectively (Galindo-Tovar et al., 2008).

As a diploid species, $P$. americana has 24 chromosomes $(2 n=24)$ and a genome size of $\approx 907 \mathrm{Mbp}$ (López-Gómez et al., 2007). It presents a blooming mechanism called synchronous protogynous dichogamy. Its flowers are perfect, and the male and female parts are functional at different times of the day. The avocado genotypes can be classified as blooming types A or B. Type A genotypes open in the morning as functional female flowers, and then reopen the next day in the afternoon as functional male flowers; type B genotypes open in the afternoon as functional female flowers, and the next morning as functional male flowers. It is thought that this mechanism promotes outcrossing between avocado trees of opposite blooming types (Borrone et al., 2008)

Received for publication 9 July 2019. Accepted for publication 15 Oct. 2019. Published online 12 December 2019.

We thank Alejandro F. Barrientos-Priego and Satish Kumar Ponniah for their review.

A.G.-D. is the corresponding author. Email: adriana.gutierrezdz@uanl.edu.mx. This is an open access article distributed under the CC BY-NC-ND license (https://creativecommons.org/licenses/by-nc-nd/4.0/).
Molecular markers based on DNA are identifiable DNA sequences found at specific locations on the chromosomes and transmitted by the Mendelian laws of inheritance from one generation to the next one. SSRs, also known as microsatellites, are tandemly arranged repeats of mono, di-, tri, tetra-, and pentanucleotides with different lengths of repeat motifs (Bhat et al., 2010). SSR markers are characterized by their hypervariability, reproducibility, codominant nature, locus specificity, and random genome-wide distribution (Jiang, 2013). ISSRs are segments of DNA flanked at both ends by such microsatellite sequences. Based on a single primer having microsatellite sequence complementary to microsatellite regions in the genome, random DNA segments in the genome can be amplified by polymerase chain reaction (PCR; segments within an amplifiable size range) and used as markers. These markers are assumed dominant and detect variation in the size of the genomic region between the two adjacent microsatellite sequences used as the primers binding sites (Ng and Tan, 2015; Singh and Singh, 2015). To minimize human and stochastic errors, only clearly distinctive bands with strong intensities and within a standardized size range should be scored (Ng and Tan, 2015).

Molecular markers in avocado have been used to assess genetic diversity among and within racial groups (Boza et al., 2018; Cuiris-Pérez et al., 2009; Gross-German and Viruel, 2013), in phylogenetic studies (Ashworth and Clegg, 2003; Reyes-Alemán et al., 2013), and in construct linkage maps (Borrone et al., 2009); to identify quantitative trait loci (Sharon et al., 1998), and in outcrossing studies (Alcaraz and Hormaza, 2011; Borrone et al., 2008; Chen et al., 2007; Garner et al., 2008; Kobayashi et al., 2000; Schnell et al., 2009; Violi et al., 2009). Outcrossing rate studies based on molecular markers 
have been done in different plant species such as Brassica carinata A. Braun (Teklewold et al., 2013), Foeniculum vulgare Mill. (Salami et al., 2017), Olea europaea L. (Souza et al., 2012), Passiflora alata Curtis (Ferreira et al., 2010), Pinus densiflora Sieb. and Zucc. (Lian et al., 2001), Sorghum bicolor (L.) Moench (Adugna, 2012), Spondias tuberosa Arruda (Fernandes and Cândido de Souza, 2013), Theobroma cacao L. (Efombagn et al., 2009), T. grandiflorum (Willd. ex Spreng.) Schum (Alves et al., 2003), and Warburgia ugandensis Sprague (Muchugi et al., 2008) to propose effective schemes for germplasm conservation and/or to establish strategies of selection and improvement.

In avocado, most outcrossing studies have been done in cultivars such as Hass, Bacon, Zutano, and others (Kobayashi et al., 2000; Schnell et al., 2009) to detect potential donors of pollen and to calculate the correlation between outcrossing and yield (Kobayashi et al., 2000), to determine the incidence and effectiveness of self- and cross-pollinated avocado fruit (Davenport et al., 2006), and to assess the relation among outcrossing rate with yield and alternate bearing (Garner et al., 2008). In addition, the outcrossing rate has been used to assess the proportion of progeny resulting from parents with complementary blooming (Borrone et al., 2008; Violi et al., 2009) and to determine whether an outcrossed progeny is more tolerant to Phytophthora root rot than a self-pollination progeny (Violi et al., 2009). However, the outcrossing rate results presented in all studies show variation according to location, tree distribution within orchards, and genotypes used as potential pollen donors.

In past decades, native Mexican avocado populations have been threatened due to the destruction of their ecosystems-a result of the opening of new areas for agricultural and livestock production; factors such as overgrazing, forest fires, urban area expansion, and logging (Torres-Gurrola et al., 2009); the presence of soil diseases and drought (Barrientos-Priego and López-López, 2002); and their replacement by improved cultivars or high productivity hybrids (Rincón-Hernández et al., 2011). Therefore, it is important to understand the biology of pollination to develop effective strategies to conserve the diversity of these genetic resources for future crop improvement.

It is assumed that avocado blooming behavior is a sophisticated mechanism that prevents effective self-pollination (within a flower), enables close pollination (between neighboring flowers within a tree), and encourages cross-pollination (between different cultivars), according to Ish-Am (2005). There is no information on outcrossing rate among Mexican race avocado genotypes. Therefore, the objective of this study was to assess the outcrossing rate and genetic variability in progenies of Mexican race avocado genotypes by SSR and ISSR markers, which will enable the establishment of new strategies for the conservation and genetic improvement of outstanding native genotypes.

\section{Materials and Methods}

\section{Plant material and DNA extraction}

This research was carried out at the Agronomy School of Universidad Autónoma de Nuevo León in Mexico during Summer 2017. Progenies of 10 Mexican race avocado genotypes from the state of Nuevo León with contrasting morphological traits were used. Genotypes 'Bola', 'Criollo 3', 'Criollo 6', 'Leonor', 'María Elena', 'Plátano', 'Plátano Delgado',
'Plátano Temprano', and 'Todo el Año' were in an orchard at the municipality of Aramberri (lat. 24.06 $28.8^{\prime \prime} \mathrm{N}$, long. $99^{\circ} 49^{\prime} 42.4^{\prime \prime} \mathrm{W}$; elevation, $1080 \mathrm{~m}$ ). These genotypes are local germplasm resources that have been adapted and selected empirically by the farmers. 'Silvestre' genotype (single tree) was growing in a forest environment at the municipality of General Zaragoza (lat. 235 $7^{\prime} 18.573^{\prime \prime} \mathrm{N}$, long. 99 $46^{\prime} 17.27^{\prime \prime} \mathrm{W}$; elevation, $1432 \mathrm{~m}$ ). Each genotype is a seed parent (mother tree) and its progeny is a half-sib family. Twenty mature fruit were collected from each genotype (one tree per genotype) and kept separately. Seeds from each fruit were extracted and washed. The seeds were raised under greenhouse conditions in individual pots containing a mix of peatmoss, perlite, and vermiculite in proportions $3: 1: 1$ as a substrate. After 3 months of establishment, 12 healthy seedlings were selected randomly by genotype for genomic DNA extraction. DNA was extracted from leaves using the extraction buffer described by Cheng et al. (1997), during which the cetyltrimethylammonium bromide concentration was increased to $650 \mu \mathrm{M}$. For DNA precipitation and washing steps, washing buffer solutions 1 and 2 indicated by Hoisington et al. (1994) were used. DNA was also isolated from mother trees. The integrity, quality, and quantity of DNA were assessed in $0.8 \%$ agarose gel and by spectrophotometry (Cheng et al., 1997). The DNA was diluted to a working concentration of $10 \mathrm{ng} \cdot \mu \mathrm{L}^{-1}$ in TrisEDTA (TE) buffer (10 mm Tris-HCl, 1 mm Na 2 EDTA, pH 8.0).

\section{SSR markers}

The PCR reactions were carried out in a $15-\mu \mathrm{L}$ volume containing molecular biology-grade water (Sigma-Aldrich, St. Louis, MO) $1 \times$ PCR buffer (Promega, Madison, WI), $2 \mathrm{~mm}$ $\mathrm{MgCl}_{2}, 0.4 \mathrm{~mm}$ deoxyribonucleotide triphosphate (dNTP) mix (Promega), 0.01\% polyethylene glycol sorbitan monolaurate (Tween ${ }^{\circledR}$ 20, Sigma-Aldrich), $0.4 \mu \mathrm{M}$ each primer, 25 ng DNA template, and 0.5 U GoTaq ${ }^{\circledR}$ Flexi DNA Polymerase (Promega). Four primer pairs developed by Gross-German and Viruel (2013) and one primer pair developed by Ashworth et al. (2004) were used (Table 1). DNA amplifications were conducted in a thermal cycler (Applied Biosystems Veriti PN 4375786; Thermo Fisher Scientific, Waltham, MA). The thermal program started with a denaturing step at $94{ }^{\circ} \mathrm{C}$ for $1 \mathrm{~min}$ followed by 35 cycles of $30 \mathrm{~s}$ at $94{ }^{\circ} \mathrm{C}, 30 \mathrm{~s}$ at the specific annealing temperature for each primer, and $1 \mathrm{~min}$ at $72{ }^{\circ} \mathrm{C}$; and a final extension step of $5 \mathrm{~min}$ at $72^{\circ} \mathrm{C}$. PCR products were separated by electrophoresis in $4 \%$ agarose gel at $120 \mathrm{~V}$ for $3.5 \mathrm{~h}$, stained with SYBR Gold nucleic acid gel stain (Invitrogen, Eugene, OR), and visualized using an ultraviolet light transilluminator. The band sizes were estimated using a 25-bp DNA ladder (HyperLadder; Bioline, Boston, MA) and scored by their molecular weight.

\section{ISSR markers}

PCR was carried out in a $25-\mu \mathrm{L}$ volume containing molecular biology-grade water, $1 \times$ PCR buffer (Promega), $3 \mathrm{~mm}$ $\mathrm{MgCl}_{2}, 0.25 \mathrm{~mm}$ dNTP mix (Promega), $0.2 \mu \mathrm{M}$ primer, $50 \mathrm{ng}$ DNA template, and $1 \mathrm{U}_{\text {GoTaq }}{ }^{\circledR}$ Flexi DNA Polymerase (Promega). Four ISSR primers were used because of their high percentage of polymorphism $(>80 \%)$ reported previously by Reyes-Alemán et al. (2013) (Table 2). DNA amplifications were conducted in a thermal cycler (Applied Biosystems Veriti PN 4375786). The thermal program started with a denaturing step at $94{ }^{\circ} \mathrm{C}$ for $2 \mathrm{~min}$ followed by 45 cycles of $1 \mathrm{~min}$ at $94{ }^{\circ} \mathrm{C}$, $1 \mathrm{~min}$ at the specific annealing temperature for each primer, and 
Table 1. Simple sequence repeat description and genetic variation parameters per locus of Mexican race avocados.

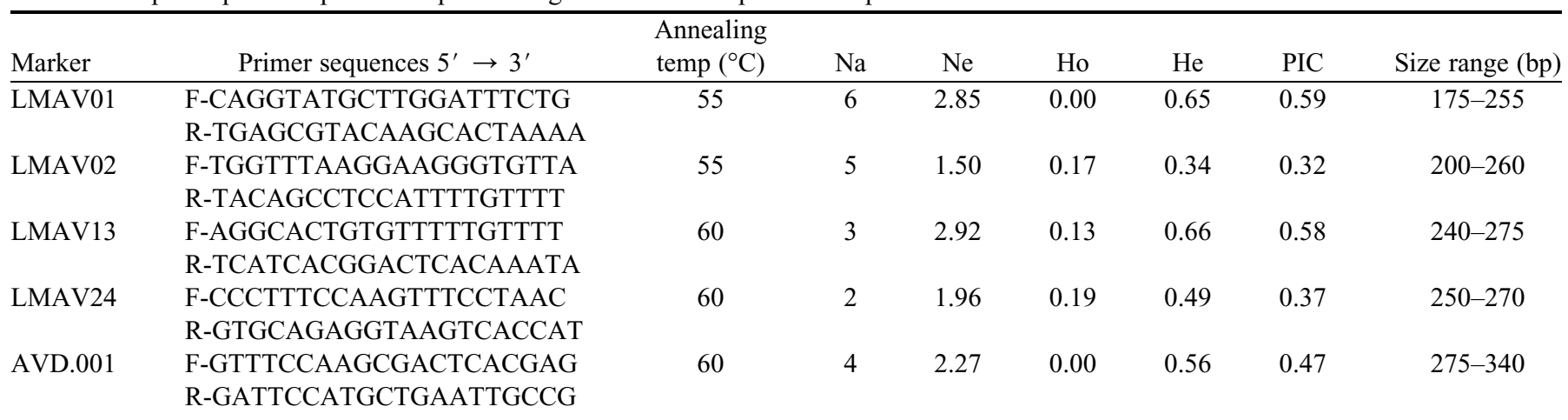

$\mathrm{Na}=$ number of alleles per locus; $\mathrm{Ne}=$ number of effective alleles; Ho = observed heterozygosity; He = expected heterozygosity; PIC = polymorphism information content.

Table 2. Intersimple sequence repeat (ISSR) description and summary per primer of Mexican race avocados.

\begin{tabular}{|c|c|c|c|c|c|c|c|}
\hline & Primer & Annealing & & polym & & & \\
\hline Marker & sequences $5^{\prime} \rightarrow 3^{\prime}$ & temp $\left({ }^{\circ} \mathrm{C}\right)$ & No. of bands & bands & Amplification (\%) & $\mathrm{nHe}$ & PIC \\
\hline$\overline{\text { ISSR1 }}$ & $(\mathrm{AC})_{8} \mathrm{YG}$ & 53 & 14 & 14 & 47 & 0.50 & 0.37 \\
\hline ISSR2 & $(\mathrm{GACA})_{4}$ & 53 & 8 & 8 & 42 & 0.49 & 0.37 \\
\hline ISSR5 & $(\mathrm{GA})_{8} \mathrm{YC}$ & 48 & 6 & 4 & 63 & 0.47 & 0.36 \\
\hline
\end{tabular}

$\overline{\mathrm{nHe}}=$ Nei's unbiased average heterozygosity; PIC = polymorphic information content .

2 min at $72^{\circ} \mathrm{C}$; and a final extension step of 7 min at $72^{\circ} \mathrm{C}$. PCR products were separated by electrophoresis in 3\% agarose gel at $120 \mathrm{~V}$ for $3 \mathrm{~h}$, stained with SYBR Gold nucleic acid gel stain (Invitrogen), and visualized in ultraviolet light. The band sizes were estimated using a 100-bp DNA ladder (Axygen Biosciences, Union City, CA) and scored into a binary character matrix ( 1 for presence and 0 for absence).

\section{Data analyses}

Genetic VARIation. With SSR data, the number of alleles per locus $(\mathrm{Na})$, number of effective alleles $(\mathrm{Ne}), \mathrm{Ho}, \mathrm{He}$, and polymorphism information content (PIC) were calculated. For the ISSR data description, the number of total bands $(\mathrm{Nb})$, number of polymorphic bands $(\mathrm{Np})$, PIC, percentage of amplification, and nHe were calculated. Along with the genotypic data of each kind of marker, a hierarchical genetic variation among families, including individuals within families, was estimated using nonparametric AMOVA, with 10,000 permutations using the distance method (Balzarini et al., 2010). These analyses were performed using InfoGen version 2016 (Balzarini and Di Rienzo, 2016).

Outcrossing RATE PARAmeters. For population level, the data of both types of markers were analyzed using the multilocus mixed mating program, version 3.2 (Ritland, 2002), which assumes that progenies are the product of either outcrossing or self-fertilization. The estimated parameters were multilocus outcrossing rate $\left(t_{m}\right)$, single-locus outcrossing rate $\left(t_{s}\right)$, full siblings rate $\left(t_{m}-t_{s}\right)$, fixation index for maternal genotypes $\left(F_{m}\right)$, correlation of outcrossed paternity $\left(r_{p}\right)$, probable number of pollinators $\left[1 / r_{p}\right]$, and correlation of selfing among loci $\left(r_{s}\right)$. These parameters were estimated using maximum likelihood procedures and the Newton-Raphson method. Standard deviation for each parameter was calculated based on 500 bootstraps. For family level, only $t_{m}, t_{s}$, and $t_{m}-t_{s}$ were estimated using codominant data.

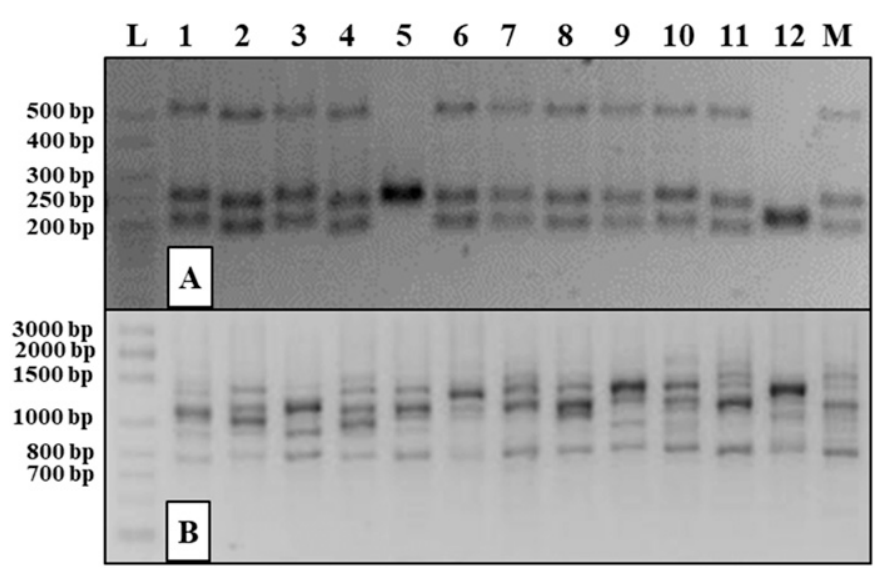

Fig. 1. Example of electrophoretic profiles of amplified genomic DNA fragments of 'Leonor' avocado family. (A) Profile obtained with the simple sequence repeat primers LMAV02. (B) Profile obtained with the intersimple sequence repeat primer ISSR2. $\mathrm{L}=$ ladder; $1-12$ = seedlings; $\mathrm{M}=$ mother tree.

\section{Results and Discussion}

Performance of SSR markers. Five polymorphic SSR loci amplified a total of 20 alleles (Fig. 1A), with an average of four alleles per locus, varying from two (LMAV24) to six (LMAV01), and with a size range of 175 to $340 \mathrm{bp}$ (Table 1). The allele frequency mean was 0.192 and frequencies varied from 0.008 to 0.480 . The average $\mathrm{Ne}$ (number of effective alleles) value was 2.3. Ho was 0.098 and ranged from 0.00 (LMAV01, AVD.001) to 0.19 (LMAV24). He was 0.54 and ranged from 0.34 to 0.66 for loci LMAV02 and LMAV13, respectively. The average PIC value was 0.47 , with the greatest value found in LMAV01 $(\mathrm{PIC}=0.59)$ and the least in LMAV02 $(\mathrm{PIC}=0.32)$. These PIC values are like those 
Table 3. Heterozygosity estimates, multilocus outcrossing rate $\left(t_{m}\right)$, single locus outcrossing rate $\left(t_{s}\right)$, and full siblings rate $\left(t_{m}-t_{s}\right)$ per Mexican race avocado family.

\begin{tabular}{|c|c|c|c|c|c|c|}
\hline \multirow[b]{2}{*}{ Family } & \multicolumn{2}{|c|}{ SSR } & \multirow{2}{*}{$\frac{\mathrm{ISSR}}{\mathrm{nHe}}$} & \multirow[b]{2}{*}{$t_{\mathrm{m}}$} & \multirow[b]{2}{*}{$t_{s}$} & \multirow[b]{2}{*}{$t_{m}-t_{s}$} \\
\hline & Ho & $\mathrm{He}$ & & & & \\
\hline Bola & 0.083 & 0.492 & 0.488 & $0.420(0.143)^{\mathrm{z}}$ & $0.079(0.027)$ & $\overline{0.341(0.140)}$ \\
\hline Criollo 3 & 0.067 & 0.212 & 0.478 & $-0.083(0.031)$ & $-0.021(0.008)$ & $-0.062(0.030)$ \\
\hline Criollo 6 & 0.017 & 0.167 & 0.496 & $0.086(0.082)$ & $0.018(0.017)$ & $0.068(0.080)$ \\
\hline Leonor & 0.233 & 0.177 & 0.504 & $0.687(0.067)$ & $0.297(0.048)$ & $0.390(0.047)$ \\
\hline María Elena & 0.083 & 0.334 & 0.498 & $0.109(0.091)$ & $0.059(0.056)$ & $0.050(0.072)$ \\
\hline Plátano & 0.167 & 0.291 & 0.495 & $0.436(0.152)$ & $0.149(0.052)$ & $0.287(0.143)$ \\
\hline Plátano Delgado & 0.050 & 0.340 & 0.511 & $0.170(0.110)$ & $0.082(0.053)$ & $0.088(0.096)$ \\
\hline Plátano Temprano & 0.267 & 0.349 & 0.494 & $0.814(0.060)$ & $0.362(0.042)$ & $0.452(0.043)$ \\
\hline Silvestre & 0.000 & 0.278 & 0.505 & $0.000(0.001)$ & $0.000(0.001)$ & $0.000(0.000)$ \\
\hline Todo el Año & 0.017 & 0.341 & 0.488 & $0.085(0.081)$ & $0.016(0.015)$ & $0.069(0.080)$ \\
\hline Total & 0.098 & 0.540 & 0.482 & $0.774(0.091)$ & $0.431(0.063)$ & $0.342(0.113)$ \\
\hline
\end{tabular}

${ }_{\mathrm{zD}}$ based on 500 bootstraps.

$\mathrm{SSR}=$ simple sequence repeat; ISSR = intersimple sequence repeat; Ho = observed heterozygosity; $\mathrm{He}=$ expected heterozygosity; $\mathrm{nHe}=$ Nei's unbiased average heterozygosity.

Table 4. Analysis of molecular variance for 10 families of Persea americana var. drymifolia based on simple sequence repeat and intersimple sequence repeat markers with 10,000 permutations using the distance method.

\begin{tabular}{lrrrccc}
\hline Source of variation & Df & SS & MS & $\begin{array}{c}\text { Variance } \\
\text { component }\end{array}$ & Variation (\% total) & $P$ value \\
\hline Among populations & 9 & 378.294 & 42.033 & 3.29 & 41.40 & $<0.0001$ \\
Within populations & 104 & 483.592 & 4.650 & 4.65 & 58.60 & $<0.0001$ \\
Total & 113 & 861.886 & 7.627 & & & \\
\hline
\end{tabular}

$\mathrm{SS}=$ sum of squares; MS = mean squares.

reported by Efombagn et al. (2009), which ranged from 0.19 to 0.82 . The number of alleles per locus was expected to be low as a result of the closely related individuals in the populations. The results obtained for $\mathrm{Na}, \mathrm{He}$, and $\mathrm{PIC}$ indicate that these kinds of markers are useful for determining genetic variation within and among populations of closely related individuals (Efombagn et al., 2009), as well as for calculating the degree of inbreeding within and among populations (Boza et al., 2018; Gross-German and Viruel, 2013).

Performance of ISSR markers. A total of 33 clear and reproducible bands were amplified with the four ISSR primers used (Fig. 1B), with an average of 8.25 bands per primer and a size range of 500 to $3000 \mathrm{bp}$. Thirty-one amplified bands (93\%) were polymorphic, and three of four primers were $100 \%$ polymorphic. The $\mathrm{Nb}$ and amplification per primer ranged from 5 (ISSR4) to 14 (ISSR1), and from $42 \%$ (ISSR2) to $63 \%$ (ISSR4 and ISSR5), respectively. The PIC and nHe values were very similar for all primers, with averages of PIC $=0.365$ and $\mathrm{nHe}=0.482$ (Table 2). The average values of $\mathrm{Nb}$, the percentage of polymorphic bands, and the average PIC value per ISSR primer are like those reported by Fasih et al. (2013) in populations of Festuca arundinacea Schreb. They obtained values of $\mathrm{Nb}$ that ranged from 4 to 13 , percentages of polymorphic bands from $50 \%$ to $100 \%$, and an average PIC value of 0.32 . These results confirm the usefulness of the ISSR markers in estimating genetic variation among relatively close individuals exhibiting low levels of polymorphism (Reyes-Alemán et al., 2013), and they contrast with the values obtained when it comes to distinguishing genotypes with diverse origins (average $\mathrm{Nb}=22,100 \%$ of polymorphic bands, and average PIC = 0.92) (Cuiris-Pérez et al., 2009).
Ho, He, AND AMOVA FOR AVOCADO FAMILIES. Considering that heterozygosity is a measure of genetic diversity (Galindo-Tovar et al., 2011), with SSR markers, the total He value $(0.540)$ showed a considerable genetic differentiation among avocado families, whereas the total Ho value (0.098) showed the presence of genetic structure per family (Table 3 ). The 'Silvestre' family presented the lowest value of Ho (0.000) and the 'Plátano Temprano' family, the highest value Ho (0.267). On the other hand, He values ranged from 0.167 to 0.492 for families 'Criollo 6 ' and 'Bola', respectively. Ho values close to zero within avocado families could be the result of a high inbreeding rate or low rate of crosspollination as result of a lack of pollen donors or adverse environmental conditions that interfered during the pollination stage. The $\mathrm{nHe}$ values found with ISSR markers were very similar for all families. Total $\mathrm{nHe}$ was 0.482 and ranged from 0.478 to 0.511 for families 'Criollo 3' and 'Plátano Delgado', respectively. These results showed a low genetic variability within avocado families and also demonstrated that ISSR markers are an efficient tool to identify genotypes, even among closely related individuals and a rather small sample size (Thangjam, 2014; Tuisima et al., 2016). According to Nei (1978), the number of individuals for estimating genetic distance can be very small $(\leq 10)$ if the number of loci is more than 50 , or if the genetic distance is large, and the average heterozygosity of the two species compared is low. Even a single individual may be enough for obtaining the correct topology of a dendrogram if the differences are large. Using dominant markers such as ISSRs, the minimum number of markers required and number of individuals to be sample depend on many factors, including level of neutral genetic diversity, population differentiation, migration, unequal sample sizes, and the analyses to be performed. For AMOVAs, as few as 30 markers and sampling between 5 to 10 individuals yield reliable results (Nelson and Anderson, 2013). AMOVA results for each kind of marker were similar and highly significant $(P<0.0001)$. Genetic variation among individuals within families of avocado genotypes was $69.17 \%$ and among families was $30.83 \%$ with SSR, whereas with ISSR it was $63.37 \%$ and $36.63 \%$, respectively. AMOVA results combining both types of markers showed that genetic variation within families was $58.6 \%$ and among families was $41.6 \%(P<$ $0.0001)$. In this case, codominant data were transformed manually to dominant (Table 4).

Outcrossing population Rate parameters. The results with both types of markers showed a $t_{m}$ of $0.774 \pm 0.091$, indicating that $P$. americana var. drymifolia is predominantly outcrossed with a small amount of selfing $(22.6 \%)$. The $t_{s}$ was $0.431 \pm 0.063$, and $t_{m}-t_{s}$ was $0.342 \pm 0.113$, indicating full 
siblings occurring among families. The correlation of outcrossed population paternity indicates the probability that two siblings are outcrossed full-sibs (Ritland, 2002). In our study, the population value was $r_{p}=0.525 \pm 0.125$, showing the presence of full siblings or nonrandom mating, which means the number expected of pollen donors was low. The ratio $1 / r_{p}$ estimates the probable number of effective pollen donors; in this case, the number of potential male parents involved in each progeny was 1.9 , suggesting that, on average, two pollinators contributed to the crosses. Another way to estimate the outcrossing rate is by means of the fixation index for maternal genotypes. Here, $F_{m}$ was equal to $0.166 \pm 0.063$, indicating the occurrence of inbreeding in the maternal generation and supporting that $P$. americana var. drymifolia is a moderate to high outcrossing species. Correlation of selfing among loci approximates the fraction of selfing rate (as opposed to fullsiblings rate) (Ritland, 2002). In our study, its value was very low $\left(r_{s}=0.022 \pm 0.127\right)$, and because this value is positive, it implies that any two selfed progeny samples from the same parent are not the result of two independent selfing events (Muchugi et al., 2008). Selfing occurrence results in complete correlation of selfing among loci, whereas full siblings result in a looser correlation (Ritland, 2002).

Outcrossing family Rate Parameters. 'Criollo 3' and 'Plátano Temprano' families showed the lowest and highest values of $t_{m}, t_{s}$, and $t_{m}-t_{s}$ respectively (Table 3 ). The negative values for outcrossing estimates in the 'Criollo 3' family can be explained by a possible overrepresentation of homozygous individuals within this family. The 'Silvestre' family showed values of zero for the three estimates. These results were expected because the mother tree grows in a forest environment, isolated from any pollen donors. 'Todo el Año' is characterized by producing flowers throughout the year. Its low outcrossing values are explained because of forwardness in its blooming period in comparison with the others genotypes, which implies an absence of pollen donors and, consequently, low allelic abundance in its progeny. 'Criollo 6', according to the description given by the growers, presents early onset of fruit production in comparison with the rest of the genotypes, which explains the low outcrossing rate in its progeny. The moderate to high values for the outcrossing estimates in the families 'Bola', 'Plátano', 'Leonor', and 'Plátano Temprano' indicate the existence of outcrossing within the families; their positive values of $t_{m}-t_{s}$ indicate a moderate level of fullsiblings rate. These results are expected because of their overlapping blooming periods and proximity, and because other unsampled trees surround them.

Traditionally, it has been accepted that natural hybridization in avocado is controlled by flower type A (open as female during the morning and reopen as male the following afternoon) and type B (first open as female in the afternoon and reopen as male the next morning) restricting or even preventing selfpollination (Boza et al., 2018). However, several studies have revealed that cross-pollination is not always maintained, and that self-pollination can be favored by several factors. In Florida, Davenport et al. (1994) indicated a self-pollination rate of $90 \%$ to $95 \%$ for avocado flowers. Moreover, Borrone et al. (2008), detected an avocado outcrossing rate average of $85 \%$, with $96 \%$ for 'Tonnage' vs. $74 \%$ for 'Simmonds', and the identity of the potential pollen donor varied, demonstrating that, under certain conditions, high levels of outcrossing can occur. Outcrossing rates values of 'Hass' ranging from $6.6 \%$ to
$100 \%$ for seven California 'Hass' orchards, with an average of $31.4 \%$, were reported by Kobayashi et al. (2000). They conclude that both climatic region and proximity to a pollen source are important factors controlling the mating process. Davenport et al. (2006) found that $68 \%$ of fruit in southern California was self-pollinated; in addition, they concluded that the proportion of self-pollination vs. cross-pollination might be influenced by cool weather conditions to which the trees are exposed. Garner et al. (2008) found a range of outcrossing rates for individual trees of $0 \%$ to $68 \%$ (average, $11 \% \pm 5 \%$ ). They mentioned that numerous factors could limit outcrossing rates, including the degree of blooming overlap between 'Hass' and pollen donors, the pollinizer effectiveness, the distance of 'Hass' trees to the nearest pollen donor, and the weather conditions, with cool day- and nighttime air temperatures that cause the outcrossing mechanism to break down, resulting in close pollination among 'Hass' trees. Alcaraz and Hormaza (2011), using a single SSR locus (AVAG21), found that the outcrossing rate of 'Hass' by 'Fuerte' at commercial harvest ranged from $32 \%$ to $68 \%$ in 2005 and from $31 \%$ to $74 \%$ in 2006 . They reported that a high proportion of self-fertilized fruit was derived from flowers fertilized during the last weeks of the 'Hass' blooming season when 'Fuerte' presented either few or no flowers, and a decrease in the percentage of fruit derived from outcrossing with increasing distance to the pollinators. The results of the outcrossing rates in $P$. americana reported in these studies coincide with those found in our research, allowing us to conclude that 1) the outcrossing rates in $P$. americana var. drymifolia are very variable and depend on many factors, including as edaphoclimatic, agronomic and genetic; 2) this variability needs to be considered to define strategies for the conservation and genetic improvement of outstanding native genotypes; and 3) SSR and ISSR markers are useful for estimating genetic variability within and among families of avocado, as well as for determining the outcrossing rates among closely related individuals and with a rather small sample size.

\section{Literature Cited}

Adugna, A.A. 2012. Population genetics and ecological studies in wild sorghum [Sorghum bicolor (L.) Moench] in Ethiopia: Implications for germplasm conservation. Addis Ababa University, Addis Ababa, Ethiopia. PhD Diss.

Alcaraz, M.L. and J.I. Hormaza. 2011. Influence of physical distance between cultivars on yield, outcrossing rate and selective fruit drop in avocado (Persea americana, Lauraceae). Ann. Appl. Biol. 158:354-361.

Alves, R.M., A.S. Artero, A.M. Sebbenn, and A. Figueira. 2003. Mating system in a natural population of Theobroma grandiflorum (Willd. ex Spreng.) Schum., by microsatellite markers. Genet. Mol. Biol. 26:373-379.

Ashworth, V.E.T.M. and M.T. Clegg. 2003. Microsatellite markers in avocado (Persea americana Mill.): Genealogical relationships among cultivated avocado genotypes. J. Hered. 94:407-415.

Ashworth, V.E.T.M., M.C. Kobayashi, M. de la Cruz, and M.T. Clegg. 2004. Microsatellite markers in avocado (Persea americana Mill.): Development of dinucleotide and trinucleotide markers. Scientia Hort. 101:255-267.

Balzarini, M.G., C. Bruno, A. Peña, I. Teich, and J. Di Rienzo. 2010. Estadística en biotecnología: Aplicaciones en Info-Gen. Encuentro Grupo Editor, Córdoba, Argentina.

Balzarini, M.G. and J.A. Di Rienzo. 2016. InfoGen versión 2016. 11 Nov. 2018. <http://www.info-gen.com.ar>.

Barrientos-Priego, A.F. and L. López-López. 2002. Historia y genética del aguacate, p. 100-121. In: Memoria de la Fundación 
Salvador Sánchez Colín. Centro de Investigaciones Científicas y Tecnológicas del Aguacate en el Estado de México, Coatepec de Harinas, México.

Bhat, Z.A., W.S. Dhillon, R. Rashid, J.A. Bhat, W.A. Dar, and M.Y. Ganaie. 2010. The role of molecular markers in improvement of fruit crops. Notulae Scientia Biologicae. 2:22-30.

Borrone, J.W., J.S. Brown, C.L. Tondo, M. Mauro-Herrera, D.N. Kuhn, H.A. Violi, R.T. Sautter, and R.J. Schnell. 2009. An ESTSSR-based linkage map for Persea americana Mill. (avocado). Tree Genet. Genomes 5:553-560.

Borrone, J.W., C.T. Olano, D.N. Kuhn, J.S. Brown, R.J. Schnell, and H.A. Violi. 2008. Outcrossing in Florida avocados as measured using microsatellite markers. J. Amer. Soc. Hort. Sci. 133:255-261.

Bost, J.B., N.J.H. Smith, and J.H. Crane. 2013. History, distribution and uses, p. 10-30. In: B. Schaffer, B.N. Wolstenholme, and A.W. Whiley (eds.). Avocado: Botany, production and uses. 2nd ed. CABI Publishing, Boston, MA.

Boza, E.J., C.L. Tondo, N. Ledesma, R.J. Campbell, J. Bost, R.J. Schnell, and O.A. Gutiérrez. 2018. Genetic differentiation, races and interracial admixture in avocado (Persea americana Mill.), and Persea spp. evaluated using SSR markers. Genet. Resources Crop Evol. 65:1195-1215.

Chen, H., V.E.T.M. Ashworth, S. Xu, and M.T. Clegg. 2007. Quantitative genetic analysis of growth rate in avocado. J. Amer. Soc. Hort. Sci. 132:691-696.

Cheng, F.S., S.K. Brown, and N.F. Weeden. 1997. A DNA extraction protocol from various tissues in woody species. HortScience 35:921922.

Cuiris-Pérez, H., H. Guillén-Andrade, M.E. Pedraza-Santos, J. López-Medina, and I. Vidales-Fernández. 2009. Genetic variability within Mexican race avocado (Persea americana Mill.) germplasm collections determined by ISSRs. Rev. Chapingo Ser. Hort. 15:169-175.

Davenport, T.L., P. Parnitzki, S. Fricke, and M.S. Hughes. 1994. Evidence and significance of self-pollination of avocados in Florida. J. Amer. Soc. Hort. Sci. 119:1200-1207.

Davenport, T.L., Z. Ying, and R.J. Schnell. 2006. Use of simple sequence repeats (SSR) to determine incidence and effectiveness of self-and cross-pollinated avocado fruit in southern California, Year 3 of 3. Proc. California Avocado Res. Symp. Univ. California, Riverside. 4 Nov. 2006. p. 64-80.

Efombagn, M.I., O. Sounigo, A.B. Eskes, J.C. Motamayor, M.J. Manzanares-Dauleux, R. Schnell, and S. Nyassé. 2009. Parentage analysis and outcrossing patterns in cacao (Theobroma cacao L.) farms in Cameroon. Heredity 103:46-53.

Fasih, Z., M. Farshadfar, and H. Safari. 2013. Genetic diversity evaluation of within and between populations for Festuca arundinacea by ISSR markers. Intl. J. Agr. Crop Sci. 5:14681472.

Fernandes, C.A. and R.N. Cândido de Souza. 2013. An AFLP estimation of the outcrossing rate of Spondias tuberosa (Anacardiaceae), an endemic species to the Brazilian semiarid region. Rev. Biol. Trop. 61:577-582.

Ferreira, T.G.T., H.A. Penha, M.I. Zucchi, A.A. Santos, L.R. Hanai, N. Junqueira, M.F. Braga, R. Vencovsky, and M.L.C. Vieira. 2010. Outcrossing rate in sweet passion fruit based on molecular markers. Plant Breed. 129:727-730.

Galindo-Tovar, M.E., P.A. Milagro-Pérez, J.A. Alejandre-Rosas, O.R. Leyva-Ovalle, I. Landero-Torres, H. Lee-Espinosa, and J. Murguía-González. 2011. Relaciones genéticas del aguacate (Persea americana Mill.) en siete municipios del centro de Veracruz, caracterizadas con microsatélites. Trop. Subtrop. Agroecosystems 13:339-346.

Galindo-Tovar, M.E., N. Ogata-Aguilar, and A.M. Arzate-Fernández. 2008. Some aspects of avocado (Persea americana Mill.) diversity and domestication in Mesoamerica. Genet. Resources Crop Evol. $55: 441-450$.
Garner, L.C., V.E.T.M. Ashworth, M.T. Clegg, and C.J. Lovatt. 2008. The impact of outcrossing on yields of 'Hass' avocado. J. Amer. Soc. Hort. Sci. 133:648-652.

Gross-German, E. and M.A. Viruel. 2013. Molecular characterization of avocado germplasm with a new set of SSR and EST-SSR markers: Genetic diversity, population structure, and identification of racespecific markers in a group of cultivated genotypes. Tree Genet. Genomes 9:539-555.

Hoisington, D., M. Khairallah, and D. González-de-León. 1994. Laboratory protocols. CIMMYT Applied Molecular Genetics Laboratory, Centro Internacional de Mejoramiento de Maiz y Trigo (CIMMYT), Mexico D.F., Mexico.

Ish-Am, G. 2005. Avocado pollination: A review. Presented at the New Zealand Australia Avocado Grower's Conference '05. Tauranga, New Zealand, 20-22 Sept. 2005.

Jiang, G.-L. 2013. Molecular markers and marker-assisted breeding in plants, p. 45-83. In: S.B. Andersen (ed.). Plant breeding from laboratories to fields. IntechOpen, Rijeka, Croatia.

Kobayashi, M., J.Z. Lin, J. Davis, L. Francis, and M.T. Clegg. 2000. Quantitative analysis of avocado outcrossing and yield in California using RAPD markers. Scientia Hort. 86:135-149.

Lian, C., M. Miwal, and T. Hogetsu. 2001. Outcrossing and paternity analysis of Pinus densiflora (japanese red pinus) by microsatellite polymorphism. Heredity 87:88-98.

López-Gómez, R., Y. Torres-Cárdenas, M. Chávez-Moctezuma, R. Salgado-Garciglia, B. Jiménez-Moraila, G. Corona-Armenta, and L. Herrera-Estrella. 2007. Genómica del fruto de aguacate criollo (Persea americana Mill. var. drymifolia). Presented at the Proceedings of the VI World Avocado Congress, Viña del Mar, Chile, 12-16 Nov. 2007.

Muchugi, A., G.M. Muluvi, A.J. Simons, F.N. Wachira, and R.H. Jamnadass. 2008. Estimation of out-crossing rate in a natural breeding population of Warburgia ugandensis using AFLP marker. Afr. J. Biotechnol. 7:139-146.

Nei, M. 1978. Estimation of average heterozygosity and genetic distance from a small number of individuals. Genetics 89:583590.

Nelson, M.F. and N.O. Anderson. 2013. How many marker loci are necessary? Analysis of dominant marker data sets using two popular population genetic algorithms. Ecol. Evol. 3:3455-3470.

$\mathrm{Ng}$, W.L. and S.G. Tan. 2015. Inter-simple sequence repeat (ISSR) markers: Are we doing it right? ASM Sci. J. 9:30-39.

Reyes-Alemán, J.C., E. Valadez-Moctezuma, L. Simuta-Velázco, A.F. Barrientos-Priego, and C. Gallegos-Vázquez. 2013. Distinction of species of the genus Persea by RAPD and ISSR DNA markers. Rev. Mex. Cienc. Agri 4:517-529.

Rincón-Hernández, C.A., J. de la L. Sánchez-Pérez, and F.J. EspinosaGarcía. 2011. Caracterización química foliar de los árboles de aguacate criollo (Persea americana var. drymifolia) en los bancos de germoplasma de Michoacán, México. Rev. Mex. Biodivers. $82: 395-412$.

Ritland, K. 2002. Extensions of models for the estimation of mating systems using $n$ independent loci. Heredity 88:221-228.

Salami, M., M. Rahimmalek, and M.H. Ehtemam. 2017. Genetic variability of outcross and selfed fennel based on morphological and ISSR markers. J. Agr. Sci. Technol. 19:157-172.

Schnell, R.J., C.L. Tondo, J.S. Brown, D.N. Kuhn, T. Ayala-Silva, J.W. Borrone, and T.L. Davenport. 2009. Outcrossing between 'Bacon' pollinizers and adjacent 'Hass' avocado trees and the description of two new lethal mutants. HortScience 44:15221526.

Sharon, D., J. Hillel, S. Mhameed, P.B. Cregan, E. Lahav, and U. Lavi. 1998. Association between DNA markers and loci controlling avocado traits. J. Amer. Soc. Hort. Sci. 123:1016-1022.

Singh, B.D. and A.K. Singh. 2015. Marker-assisted plant breeding: Principles and practices. Springer, New Delhi, India.

Souza, R.A.V., J.L. Ferreira, F.T. Braga, P.H. Azevedo, G.C. Sant'Ana, A.P. Ribeiro, A. Borém, and G.M.A. Cançado. 2012. 
Outcrossing rate in olive assessed by microsatellite and inter simple sequence repeat (ISSR) markers. Afr. J. Biotechnol. 11:11580-11584.

Teklewold, A., L. Velasco, and H.C. Becker. 2013. Estimation of outcrossing rate in Ethiopian mustard (Brassica carinata) using RAPD markers. Intl. J. Plant Breed. 7:7-11.

Thangjam, R. 2014. Inter-simple sequence repeat (ISSR) marker analysis in Parkia timoriana (DC.) Merr. populations from Northeast India. Appl. Biochem. Biotechnol. 172:1727-1734.

Torres-Gurrola, G., S. Montes-Hernández, and F.J. Espinosa-García. 2009. Patterns of variation and geographic distribution in foliar chemical phenotypes of Persea americana var. drymifolia. Rev. Fitotec. Mex. 32:19-30.

Tuisima, C.L.L., P. H. Čepková, B. Lojka, J.C. Weber, and S.F. AlvesMilho. 2016. Genetic diversity in Guazuma crinita from eleven provenances in the Peruvian Amazon revealed by ISSR markers. Bosque (Valdivia) 37:63-70.

Violi, H.A., J.S. Brown, C.L. Tondo, J.W. Borrone, and R.J. Schnell. 2009. Microsatellite markers reveal low breeding system efficacy and pollen contamination can limit production of full-sib avocado progeny. Scientia Hort. 120:360-366. 